\title{
DEVELOPING LEARNING MODEL OF BASIC THROW IN PHYSICAL AND HEALTH EDUCATION THROUGH GAMES FOR SECOND GRADE STUDENTS IN CENTRAL SEMARANG DISTRICT
}

\author{
${ }^{1 *}$ Selvi Atesya Kesumawati, ${ }^{2}$ Husni Fahritsani, ${ }^{3}$ Saipul Ambri Damanik \\ Correspondence: Universitas Bina Darma \\ E-mail: kesumawati@binadarma.ac.id
}

\begin{abstract}
This study aims to produce a model of basic throw through games which is useful for teachers in giving lessons to primary school students. This development model is a procedural development, because it is in accordance with the problem to be solved and the objectives to be achieved. The procedure used includes five main stages, namely: 1) conducting an analysis of the product you want to develop, 2) making an initial product of a model of basic throw through games for primary students, 3) expert validation, 4) field testing, and 5) product revision. The data are qualitative and quantitative data, while the instruments are list question and observations. Data analysis uses percentages to analyze and subject ratings to assess the feasibility, quality and acceptability of the product. The research study in a model of basic throw through games for primary students along with the development of infrastructure, regulations, and playing techniques. The model for developing basic throw through this game is proven to be feasible, of quality, then acceptable for developing the concept skills of game motion and increasing the physical fitness of primary school students, because respondents when playing ball show that the average category is quite good, meaning that this development model is average - can be demonstrated.
\end{abstract}

\section{Keywords: Development, Throw, Small Balls, Physical Education.}

\section{Introduction}

Sports that school children learn have a very important contribution, namely distributing their turn to the children to engage directly in various experiences of learning movement, sports and health which are carried out in a systematic way to produce holistic changes in individual quality. Sport is an effort to improve the quality of human life, in addition to the main goal of forming a healthy lifestyle, through exercising a person will get benefits, one of which is that the body's metabolic system will become smooth (Hardiyono, 2020). According to Giriwijoyo (2012: 13) that the provision of learning experiences is directed to produce all students playing human resources who are as reasonable as possible, in the physical, spiritual (which includes spiritual, sentimental, and psychological aspects) and social.

PJKR

https://jurnal.unimed.ac.id/2012/index.php/jpehr 
Siedentop (2004: x) explained "education through and of physical activities." Games, recreation, skills, sports, competition, then other physical activities describe the material contained in physical education, because they contain the essential quality of education (Depdiknas, 2004: 23). ).

Games represent a framework for social activity at best during childhood. Desmita (2005: 141) stated that children's portion games are fun activity materials which are carried out solely to satisfy children's activeness, but rather pocket objects that result from the activities contained. A variety of movement skills that include movement exploration and problem solving must be practiced in advance to play games which require certain movements. Games for children must be seen as a means of bouncing and applying certain movement patterns.

Competency standards for second grade students of primary school, namely: engineering basic movement of throw and securing objects of various sizes in elementary play, cooperation, tolerance, sportsmanship and consequence. That the modification of the basic movement of throw through games needs to be done for second grade students who are adjusted to their characteristics so as to achieve effective learning. The development of the physical education learning model describes efforts to solve the problem of fixing the facilities and infrastructure for learning activities in schools. Through games, it is hoped that you can increase the basic movement of throw according to the physical characteristics of second graders, because by stimulating motor development, children can grow and develop optimally.

Pangrazi (2004: 4) stated that it is a comprehensive fraction of the complete method in education that offers development assistance and total increase of students, especially movement activities. Without physical education, the mobile learning system in schools will be lame. The three most important things of physical education, namely increasing the fitness of students, extending the mastery of rich physical dexterity, increasing students' understanding of basic movements and also how to apply them seriously. Fitness and health can be achieved with a conceptual, structured and persistent physical education calendar.

Lutan (2001: 21) stated that basic movement abilities can be used in various games, sports, and physical activities that take place at any time. When sharing understanding, the teacher must master the talents, interests and uniqueness of the child, and have the capacity to be the closest mentor in order to deepen and live their aspirations. The specification of children is that they like to play, animals, get used to and learn, as well as traditional games (Artantri, 2005: 8).

Playing as a supplier of energy that is too much if it continues to be embedded can trigger tension in children, anxiety and easily discouraged. The game plays an important role in developing and enhancing various basic movement abilities, if the appropriate game is played into the movement development agenda. Games are often given to children to optimize fun or strengthen certain skills. The game holds real values, so it must be controlled from 
a developmental perspective. Therefore, games should be selected and applied to certain abilities such as locomotor, non-locomotor and manipulative movement.

Yoyo Bahagia, et al (2000: 94) stated, "the basic movement characteristics of throw are basically similar to throw movements in other sports. Throw is, in principle, the skill of moving an object through the air by using the hand. The movement of throw mainly involves the muscles of the hands and shoulders. Forces like the hand muscles, the shoulder muscles are structured to enhance the experience of movement". This is in line with what Hardiyono et al. (2019) stated that muscle strength is the most basic and very important component in basic movement, considering that strength is the driving force for any physical activity that plays a role in preventing injury and becomes a basic component of other physical components. This muscle strength is needed in performing movements such as; pulling, throwing, resisting, pushing and lifting.

The meaning stated in the term Physical Education and Health is not only physical education but broader involvement of educational goals as a mean and participation regarding individual life. Therefore, the physical education teacher must try to teach the game of throw about technique skills of it and at the same time teach how to apply it in real game situations. The relevant learning approach is a strategic approach. An approach like this invites student to separate strategic problems in the game. This problem actually coincides with the application of technical competence in certain game conditions. "The curriculum is set to create national education by describing the stages of development for students and their suitability with the environment, the interests of national development, the increase in science, technology, and arts according to the type and level of each educational unit" (Oemar Hamalik, 2005: 18)

\section{Method}

The research method of the study is quantitative descriptive as it describes things sistematically and accurately (Sugiyono, 2012). The intended abilities are the learning outcomes and students'attitudes towards hang style long jump learning after implementing problem-based learning approach.

This research was conducted at SMK N 1 Cangkringan, Sleman. The research subjects were class $\mathrm{X}$ students majoring in ATR 1 and TKRO 1 in the academic year of 2019/2020. The data collection instruments used were a learning outcome test and an attitude questionnaire towards physical education learning. The test questions consisted of ten multiple choices and three essays. Furthermore, the attitude questionnaire towards physical education learning consisted of 30 statement items measuring the cognitive, affective, and active dimensions. In addition to the two instruments, the learning implementation observation sheet instrument was also used to ensure that the problem-based learning approach could be applied with a minimum category well during each meeting in the two subject classes.

PJKR

https://jurnal.unimed.ac.id/2012/index.php/jpehr 
The learning outcome test was analyzed by determining the percentage of minimum score achievement. The attitude questionnaire towards physical education learning was analyzed descriptively by determining the total score of each student. Then, the scores were converted into 5 categories, namely Very High, High, Fair, Low, and Very Low.

The effectiveness of physical education learning material hang style long jump using a problem-based learning approach was seen from the following two points. 1) Minimum $75 \%$ of the students reached the minimum completeness criteria for the basic competency test scores, and 2) minimum $80 \%$ of the students reached the high minimum category for attitudes (Kemp, 1994: 289).

\section{Research Methods}

Research and development can be said to be research-based development, which describes a research model which is currently increasing its role in the division of useful problems in research, especially educational research and learning. Borg \& Gall in Samsudi (2004: 4) research and development is a meaningful procedure to grow or validate the products needed in education. Furthermore, it is explained that the research and development policy consist of two main objectives, namely: (1) developing the product and (2) assessing the success of the product in achieving the goal. Wasis D (2004: 6) in every development should be able to determine and make correct decisions for his research based on conditions and obstacles in the field.

The test subjects are the target users of the creation, namely second grade primary school students, primary schools located in Central Semarang District, Semarang City (SDN Kembangsari 02, SDN Pendrikan Lor 03, SDN Miroto 0102, SDN Bangunharjo 01-02, SDN Sekayu, SD NU Pungkuran, SD Muhammadiyah 13, SD Masehi Poncol, SD Al Ma'had Islam).

Suharsimi Arikunto (2006: 149) said that an instrument is a tool when researching by utilizing structured material. The statistics used in this study are qualitative and quantitative data. Qualitative materials were obtained from the results of questions and answers in the form of criticism, input from physical education experts and sources in verbal or written words such as instructions for product perfection. Meanwhile, the quantitative data were obtained by quoting the results of the lower grade students' throws regarding the effect of using the product.

In this development research, data analysis techniques are needed, namely using descriptive analysis techniques in the form of percentages. Then the suggestions and reasons are determined with the answers analyzed using qualitative analysis techniques. In the percentage data, the formula from Sukirman (2004: 879) is accepted.

\section{Results And Discussion}


(1) analysis of the objectives and characteristics of the basic throw through games for primary school students, (2) individual elaboration of primary school students, (3) examining the literature on the basis of making / describing modification of the basic throw through play, (4) determining the principlesprinciples for the development model of the basic throw modification through play, (5) enforcing the objectives, content, and implementation of learning, (6) steps to calculate learning outcomes, and (7) accumulating initial results in the form of modification of the basic movement material for throwing through small ball games.

The initial product of the modification model of the basic throw through appropriate games for students before being tested during the small group test must be validated by experts with the point of view of this research. To validate the product to be realized, researchers included experts who were centered on primary physical education lecturers and teachers.

Based on the calculation of the questionnaire carried out by each expert and physical education teacher, it got an average of 3.4 (three point four) or more people who judge it is in the feasible category for use, so the conclusion is that the modification of the basic throw learning material by using a small ball at students can be utilized during small-scale trials.

After the small-scale trial of development model of basic throw through the game was validated by experts and physical education teachers and it was determined that there was an improvement, then the product was applied to second grade primary school students. The trials were carried out on students of SD Tunas Harum Bangsa, SD Al Ma'had and SD Masehi Poncol. This experiment intended to identify various problems such as shortcomings, difficulties, and ineffectiveness so that they can be used by students.

The development model of basic movement learning of throwing through games has been tested on a small scale and has been reviewed, the next step was to carry out large-scale trials. Large-scale trials were carried out in 7 elementary schools, namely: SDN Pendrikan Lor 03, SD NU Pungkuran, SD Muhammadiyah 13, SDN Bangunharjo 01, SDN Miroto, SDN Sekayu, SDN Kembangsari 02. The number of subjects required in the large-scale trial was 196 for second grade students.

Content validity is the suitability of the measuring instrument with the overall content of knowledge and skills learned by students (Adang Suherman, 2004: 37). Of the 30 items tested were applied to 196 students / respondents, the results of the analysis of the validity and reliability with the SPSS 20 program were declared valid and reliable. Items were declared valid because $r$ count $>r$ table (0.181-0.961>0.148) and the reliability level of Cronbach's apha was 0.963.

The distribution of the psychomotor, cognitive and affective aspects can be formulated, namely: (1) the psychomotor aspects of 196 children are quite good, with an average percentage of 50\%. (2) for the cognitive aspects of 196 children, it was classified as good, with an average percentage of 56\%. (3) for the affective

PJKR 
aspect of 196 children, it was classified as good, with an average percentage of $57 \%$.

The product obtained was in the form of a small ball game which combined all the basic movement learning materials for throwing through small ball games. Evidenced by the use of basic throw techniques through small ball games, the content of learning includes: basic throw techniques over the shoulder, basic throw techniques on the side of the body, basic throw techniques from below.

In learning, the basic movements of throwing through games, it could be a solution for the unavailability of facilities and infrastructure in schools, especially ball facilities and narrow field infrastructure. The use of a ball which is multifunctional and a field which is easily adjusted, the standard of the field, and the shape of the field could be used to create a way out to handle the basic movement learning facilities and infrastructure for throwing through small ball games.

The increase in throw skills was influenced in part by: (1) the composition and parameters of each from 3 patterned posts, making students continue to be active and feel challenged to continue throw movement. (2) the field was easy to use in all existing school conditions and the composition of the students' physical capacity made it easier for students to play. (3) the uniqueness of the ball which was small, soft and comfortable to be held by the students would please the students to throw so that the students were always active. (4) by applying the circuit model from post by post, each student could try to throw with a variety of throw movements so that it enriched the basic movement of students' throw. (5) if students' preferences increase, the students were more enthusiastic about this game so that the students' basic throw skills would also improve.

\section{Conclusion}

Based on the data obtained and the assessment of research results, conclusions can be drawn: al Education. Health and Recreation

1) This research produced a small ball game with modifications to: the size of the tool, the size of the participating players, the duration and the principle, so that it can be played even with limited facilities and infrastructure.

2) The model of modifying basic movement of throw through small ball games can be a solution for the teacher in providing variations in learning small ball games.

The model of modifying the basic movement of throw through small ball games can increase students' insight in terms of knowledge of small ball games. Then, it can develop the concept of movement to improve physical fitness.

\section{References}

Artantri, Maya (2005) Pengaruh Media Gambar Binatang terhadap Kreatifitas Siswa Kelas II pada Pengajaran Seni Tari di SD Negeri Angkasa IV 
Bandung. Skripsi Sarjana Pendidikan Jurusan Pendidikan Sendratasik Program Pendidikan Seni Tari Bandung : tidak diterbitkan

Bahagia Yoyo, dkk. 2000. Prinsip-prinsip Pengembangan dan Modifikasi Cabang Olahraga. Jakarta : Depdiknas

Borg and Gall dalam samsudi. 2005. Education Research, An Introduction. New York \& London : Longman Inc.

Departemen Pendidikan Nasional. 2004. Pengkajian Sport Development Index

(SDI). Jakarta : Direktorat Jendral Olahraga dan Lemlit UNESA

Desmita. 2005. Psikologi Perkembangan. Bandung : Remaja Rosda Karya

Dwiyogo, Wasis D. (2004). Konsep Penelitian dan Pengembangan. Pusat Kajian Kebijakan Olahraga LEMLIT UM

Giriwijoyo, Santoso,dkk. 2012. Ilmu Faal Olahraga. Bandung : FPOK UPI

Hardiyono, B (2020). Tingkat Kecemasan Bertanding sebelum Bertanding dan

Percaya Diri pada saat Bertanding Atlet Pelatda Pengprov FPTI Sumatera

Selatan. Kinestetik: Jurnal Ilmiah Pendidikan Jasmani 4 (1) 47-54. https://ejournal.unib.ac.id/index.php/kinestetik/article/view/10399

Hardiyono, B, Pratama, B. a., \& Laksana, A. A. N. P. (2019). The Effect of The

Dominant Muscle Stregth and Self Confidence on The Results Climb of

The Rock Climbing's Athlete. Jurnal Sportif: Jurnal Penelitian Pembelajaran, 5(1),124-139.

https://ojs.unpkediri.ac.id/index.php/pjk/article/view/12857

Oemar Hamalik. 2005. Proses Belajar Mengajar. Bandung: Bumi Aksara

Pangrazi, R. P. (2004). Dynamic Physical Education For Elementary School Children. (14 th ed). Menlo-park, CA : Addison-Wesley

Rusli Lutan. 2001. Asas-asas Pendidikan Jasmani. Bandung : FPOK UPI

Siedentop, Darky, et al. (2004). Complete Guide to Sport Education. USA : Human Kinetics

Suharsimi Arikunto, 2006. Prosedur Penelitian Suatu Pendekatan Praktek. Jakarta :Rineka Cipta.

Suherman, Adang. 2004. Dasar-dasar Penjaskes. Jakarta: Depdiknas

Sukirman, S. 2004. Tuntutan Belajar di Perguruan Tinggi. Bandung : Pelangi Cendekia. 